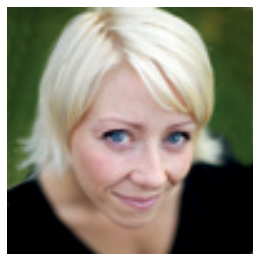

\title{
Ekte leger selger ikke ørelys
}

\begin{abstract}
Avlaten er ikke blitt noe billigere med
årene. Utvalget, derimot, er blitt

uendelig mye større. Avlaten står i et

symbiotisk forhold til sine kunder -

der det finnes anger og ønske om

sletting av synder, finnes det alltid

noen som er villig til å ta seg betalt for

tilgivelsen. Og vi angrer som aldri før.

Vi er ikke lenger redde for et helvete

som kanskje kan manifestere seg

$i$ det hinsidige. Så foreldet kan ikke

en guds menneskesyn være. Vi angrer

for å unnslippe tretthet, smerter,

hodepine, uopplagthet og manglende

overskudd. For overskudd er ikke

lenger et overskuddsfenomen,

det er et krav.
\end{abstract}

Vi skal gjøre karriere. Alle sammen. Ha det flott hjemme. Være sosiale. Forberedt på å bli omstilt eller overtallig. Samtidig som vi oppdrar barn uten bruk av kjeft eller spanskrør.

Og når vi ikke fikser livet vårt, må noe kunne endres slik at vi fikser det.

Der anorektikeren ser all mat som en skitten trussel mot den fettfrie kroppen, ser trusselbildet en del mer komplisert ut for ganske alminnelige mennesker. Hvorfor spraker jeg ikke av energi enhver mørk vintermorgen? Kanskje er det alt det grove melet og rotgrønnsakene myndighetene forsøker å prakke på folk. Kanskje er det alt sukkeret storindustrien vil utnytte din vaklende viljestyrke ved å helle i deg. Kanskje er det parasitter av ukjent opphav. Kanskje holder syrenivået $\mathrm{i}$ kroppen din egentlig på å ta livet av deg. Manglende overdoser av vitamin E eller askorbinsyre i pulverform. Og hvordan står det egentlig til med oksygennivået $\mathrm{i}$ tarmene dine? Har du tenkt nok på det? Gjort nok med det? Vært flink nok? Disiplinert nok?

Ikke rart du mangler overskudd!

Så vi angrer. Og vi kjøper avlat. Treeller 14-dagers detoxkurer som garantert skal rense oss fra all skyld, amen. Ved hjelp av tørkede urter og avføringsmidler gjør vi opp for både uansvarlig livslykke og deprimert trøstespising. Vi kjøper strømførende fotbad som skal trekke toksiner ut av systemet. Vi tror på klorofyll i tarmene, men uten ord som fotosyntese, som høres vitenskapelig, teoretisk og nesten litt ubehjelpelig ut. Og som kanskje også vil ødelegge illusjonen, fordi det minner om noe du har lært på skolen.

Men hvorfor er avlaten stadig så populær? Kanskje fordi ekte leger ikke selger ørelys. Quick-fix-ene som antibiotika og smertestillende blir enten tatt for gitt eller for å være en del av den fryktede verdensomspennende legemiddelindustrien. Og dessuten må du være ordentlig syk for å få dem.

Suget etter ikke-forskningsbasert alternativ behandling skyldes ikke mangel på kunnskap. Den som vil, kan gå inn på en tilfeldig diskusjon på nett som for eksempel dreier seg om hvilken vannrensemaskin som er best å installere i sitt eget hjem. En til 15000 eller 24000 ? Svaret sier seg egentlig selv, men helsegevinsten av å kunne velge $\mathrm{pH}$ på vannet er vel verd alt du kan avse? Prøv å argumentere med at vannet i Norge er trygt og godt, i likhet med livet i det store og det hele i dette overklasselandet vårt. Legg linker til forskning som diskrediterer $\mathrm{pH}$-teorien, parasitteorien, ørelys og fotbad, teorier om at iskrystaller er et bevis på at god energi kan lagres $\mathrm{i}$ vann for så å frigjøres i kroppen din og helbrede den - jeg kan love deg at du ikke møter takknemlighet for penger spart.

Hver gang jeg har vært til legen og bedt ham sjekke jernlagrene mine fordi jeg er så sliten, får jeg samme spørsmål: «Du har ikke for mye å gjøre, da?» Selvsagt har jeg det. Og selvsagt er jeg ute etter det samme hos legen min som hordene av mennesker som hopper på den ene alternative løsningen etter den andre - avlat. Jeg vil at noen skal slette resultatene av mitt stressende liv. Men ekte leger selger ikke ørelys. Og heller ikke jeg vil ha legens forsiktige anbefalinger om å roe litt ned, moderate livsstilsendringer, en halvtimes gåtur om dagen.

Det ironiske her er at legens anbefalinger om disse moderate livsstilsendringer koster atskillig mindre, også i en stresset hverdag. Men vi tror ikke det er sterkt nok. Legene er blitt så korrekte. Det er så jeg drømmer om den gamle legen igjen, den som kom med hvit frakk og stor autoritet, for ikke å snakke om en formidabel placeboeffekt den de alternative nå har monopol på. Nå sier ordentlige leger «kanskje», i skarp kontrast til de alternative, som ikke har noen hemninger med å si at dette kommer til å kurere deg. Selv om du ikke merker at det virker. Særlig hvis du blir verre. Inntil du eventuelt dør, men da dør du i alle fall skyldfri.

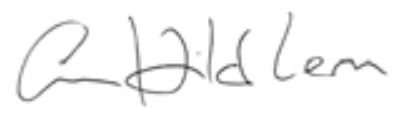

\section{I neste nummer:}

Ny operasjonsmetode
ved aortastenose
Fedmekirurgi
Eosinofil gastroenteritt

Suprakondylær humerusfraktur

- Anorexia nervosa 